\title{
Natural combination of genetic systems for degradation of phenol and resistance to heavy metals in phenol and cyanide assimilating bacteria
}

\author{
El-Deeb, B. \\ Biological Science Department, Taif University, Taif, Saudia Arabia. \\ E-mail:bahig56@yahoo.com \\ Received 23 November 2008; received in revised form 20 February 2009; accepted 1 May 2009
}

\begin{abstract}
Combination of genetic systems of degradation of xenobiotic compound and heavy metal resistance is one of the approaches to the creation of polyfunctional strains for bioremediation of soil after co-contamination with organic pollutants and heavy metals. A bacterial strain Pseudomonas putida PhCN (pPhCN1, pPhCN2) has been obtained. This bacterium contains two plasmids, a 120-kb catabolic plasmid that encodes for breakdown of phenol (pPhCN1) and pPhCN2 plasmid that codes for cadmium and copper resistant. Cyanide assimilation by this bacterium is encoded by chromosomal genes. The inhibitory effect of cadmium $\left(\mathrm{Cd}^{2+}\right)$ or copper $\left(\mathrm{Cu}^{2+}\right)$ on the degradation of phenol by $P$. putida strains $\mathrm{PhCN}$ and $\mathrm{PhCN} 1$ (contained $\mathrm{pPhCN} 1$ ) were investigated in the presence of phenol and cyanide as a sole carbon and nitrogen source, respectively. The resistant strain $\mathrm{PhCN}$ showed high ability to degrade phenol and cyanide in presence of $\mathrm{Cd}^{2+}$ or $\mathrm{Cu}^{2+}$ as compared to the sensitive strain PhCN1. In addition, $\mathrm{Cd}^{2+}$ or $\mathrm{Cu}^{2+}$ was also found to exert a strong inhibitory effect on the $\mathrm{C} 230$ dioxygenase enzyme activity in the presence of cyanide as a nitrogen source. However, the presence of heavy metal resistance plasmid alleviated the inhibitory effect of metals on the enzyme activity in resistant strain.
\end{abstract}

Keywords: bacteria, cadmium, copper, plasmid, phenol degradation

\section{INTRODUCTION}

Forty percent of hazardous wastes on the environmental protection agency's (EPA) national priority list (NPL) are co-contaminated with organic and heavy metals pollutants that pose health hazards to human and wildlife (NorenaBarrosa et al., 2004). Common organic pollutants at these sites include phenol, polycyclic aromatic hydrocarbons (PAHs), chlorinated solvents, cyanide, herbicide and pesticides, while common heavy metal contaminants include arsenic, cadmium, chromium, copper, lead, mercury, nickel, and zinc. Isolation of bacterial strains that are able to degrade more than one organic pollutants such as phenol and cyanide, is becoming increasingly important for decontaminating polluted soil, sledges, and ground water (Jain and Sayler, 1987; Chen et al., 2005). The use of these microorganisms may face various problems, including poor survival, substrate accessibility (Lin et al., 2006), or the presence of inhibitory compounds. Heavy metals are known to be powerful inhibitors of biodegradation activities (Said and Lewis, 1991; Roane and Pepper, 1997; Roane et al., 2001; Amor et al., 2001; Hong et al., 2007; Silva et al., 2007), thus, their presence may impair the biodegradation of aromatic compounds in polluted sites (Springael et al., 1993; Kuo and Genther, 1996; Benka-Coker and Ekundayo, 1998; White and Knowles, 2003; Roane et al., 2001; Sokhn et al., 2001; Riis et al., 2002; Lin et al., 2006; Silva et al., 2007; Siunova et al., 2007). Simultaneous contamination by heavy metals and organic compounds may also occur and such contamination cases had been reported before at industrial areas (Al-Saleh and Obuekwe, 2005). For this reason, there is an increasing interest (Wasi et al., 2008) in bacterial strains that are able to degrade aromatic compounds and tolerant to toxic metals. It has previously been shown that strains of Alcaligenes eutrophus bearing plasmids of metal resistance and plasmids of biodegradation of polychlorinated biphenyls and 2,4dichlorophenoxyacetic acid degrade these xenobiotics more effectively in the presence of nickel or zinc as compared to sensitive strain (Springael et al., 1993; Collard et al., 1994). However, there have been no data on the interaction of genetic systems of aromatic compounds degradation, cyanide assimilation, and metal resistance and their effect on physiology, biodegradation efficiency, and the activity of the key enzyme in multifunctional strains.

The objectives of this work are to examine the physiological and biochemical features of phenol degradation in variants of the soil strain $P$. putida $\mathrm{PhCN}$ sensitive and resistant to heavy metals, in the presence of three toxicants, cadmium $\left(\mathrm{Cd}^{2+}\right)$, copper $\left(\mathrm{Cu}^{2+}\right)$ and cyanide, as a nitrogen source. 


\section{MATERIALS AND METHODS}

\section{Chemical}

Phenol, agarose, and ethidium bromide were purchased from Sigma (St. Lous, MO, USA). Sodium cyanide, cadmium chloride $\left(\mathrm{CdCl}_{2}\right)$, nickel chloride $\left(\mathrm{NiCl}_{2}\right)$, zinc chloride $\left(\mathrm{ZnCl}_{2}\right)$ and copper chloride $\left(\mathrm{CuCl}_{2} \cdot 2 \mathrm{H}_{2} \mathrm{O}\right)$ were procured from Merck (Darmstadt, Germany). Bacteriological media were purchased from Difco (Difco Laboratories, Detroit, Michigan) and Oxoid (Oxoid Inc., Nepean, Ontario). Reagents compounds used were of the highest grade commercially available.

\section{Bacterial strains, plasmids, and culture conditions}

Bacterial strains and plasmids used in this study are listed in Table 1. $P$. putida strain PhCN was isolated from soil contaminated with pesticides and was assimilated the phenol and cyanide as a sole source of carbon and nitrogen respectively (El-Deeb, 2006). PhCN1 (pPhCN1), PhCN2 (pPhCN2) and PhCNM (plasmidless) strains were the cured derivatives of wild type strain $P$. putida. PhCN (El-Deeb, 2006). All isolates were grown aerobically at $30{ }^{\circ} \mathrm{C}$ on a rotary shaker at $150 \mathrm{rpm}$ in Luria-Bertani (LB) medium (Sambrook et al., 1989) or Tris-buffered (MSM), which was prepared according to Mergeay et al. (1985) and supplemented with phenol and $\mathrm{KCN}$ as the carbon and nitrogen sources, respectively. All isolates were maintained either on nutrient agar slants at $4{ }^{\circ} \mathrm{C}$ or in $20 \%$ $(\mathrm{v} / \mathrm{v})$ glycerol solution at $-80^{\circ} \mathrm{C}$.

\section{Effect of the presence of heavy metals on the growth} of $P$. putida PhCN and its derivatives

Bacterial cells were pre-grown in MSM with phenol (1 mM) and cyanide $(0.5 \mathrm{mM})$ in Erlenmeyer flasks at $28^{\circ} \mathrm{C}(150$ rpm) until an optical density $\left(\mathrm{OD}_{600}\right)$ of about 0.5 was reached. This culture $\left(2.2 \times 10^{5}\right)$ was used to inoculate Erlenmeyer flasks containing $1 \mathrm{mM}$ phenol and ammonium and/or cyanide as the sole source of carbon and nitrogen, respectively. The concentrations of studied heavy metals were adjusted to 10 or $100 \mu \mathrm{M}$. The initial $\mathrm{OD}_{600}$ was adjusted to about 0.05. Control flasks contained free metals medium inoculated with the same studied strains. All cultures were incubated on an orbital shaker $(150 \mathrm{rpm})$ at $28{ }^{\circ} \mathrm{C} . \mathrm{OD}_{600} \mathrm{~nm}$ was determined periodically and used as the measure of growth to construct growth curves and assess heavy metal effects on biodegradation as described by Malakul et al., (1998) and White and Knowles (2003). All tests were done in triplicate.

\section{Analytical Methods}

The phenol degradation was determined by monitoring the change in phenol concentration (Folsom et al., 1990). At different intervals of incubation, $1 \mathrm{~mL}$ samples were taken and transferred to an Eppendorff tube containing $25 \mu \mathrm{L}$ of $2 \% 4$-aminoantipyrene and $50 \mu \mathrm{L}$ of $2 \mathrm{M}$ ammonia. After mixing, $25 \mu \mathrm{L}$ of $8 \%$ potassium hexacyanoferrate (III) was added. The suspension was centrifuged at 5,000 $\times g$ for 2 min, and absorbance at $500 \mathrm{~nm}$ was measured and compared with phenol standards curve.

\section{Determination of minimal inhibitory concentration (MIC) of $\mathrm{Cd}^{2+}, \mathrm{Cu}^{2+}, \mathrm{Ni}^{2+}$, and $\mathrm{Zn}^{2+}$ against studied bacterial variants}

Minimum inhibitory concentrations (MIC) of metals for each isolate was determined by the plate-dilution method as adopted by Mergeay et al. (1985). The metals $\mathrm{Cd}^{2+}$, $\mathrm{Cu}^{2+}, \mathrm{Ni}^{2+}$, and $\mathrm{Zn}^{2+}$ were used as $\mathrm{CdCl}_{2}, \mathrm{CuCl}_{2} \cdot 2 \mathrm{H}_{2} \mathrm{O}$, $\mathrm{NiCl}_{2}$, and $\mathrm{ZnCl}_{2}$, respectively, in various concentrations ranging from 0.001 to $8 \mathrm{mM}$. The plates were incubated at 28 to $30{ }^{\circ} \mathrm{C}$ for 72 to $96 \mathrm{~h}$. The concentration of metal in which the toxicity begins to manifest was considered as the MIC of the metal against the strain tested. Carbon free Tris-salt medium (MSM) with $1.5 \%$ agar, containing phenol and ammonium or cyanide as a sole source of carbon and nitrogen respectively, was also used for detection of tolerance against these metals. The concentration of added phenol and cyanide in the media was $1 \mathrm{mM}$ and $0.5 \mathrm{mM}$, respectively.

\section{Preparation and Crude Enzyme Extract}

The effects of $\mathrm{Cd}^{2+}$ or $\mathrm{Cu}^{2+}$ were studied at the same concentration, as previously mentioned in the study of effect on growth and phenol degradation. P. putida strain $\mathrm{PhCN}$ and its derivatives were grown overnight in MSM containing $0.5 \mathrm{mM}$ phenol. Then, the culture was diluted in fresh LB medium, LB medium plus $0.5 \mathrm{mM}$ phenol, or MSM containing either ammonium or $\mathrm{KCN}$ as a sole

Table 1: Bacterial strains and plasmids

\begin{tabular}{lll}
\hline Strains or plasmids & \multicolumn{1}{c}{ Relevant characteristic(s) } & Reference or source \\
\hline Pseudomonas putida & & \\
PhCN & $\mathrm{Ph}^{+}, \mathrm{Cd}^{r}, \mathrm{Cu}^{\mathrm{r}}$, wild type pPhCN1, pPhCN2 carrier & El-Deeb (2006) \\
PhCN1 & $\mathrm{Ph}^{+}$a cured mutant of PhCN, pPhCN1 carrier & El-Deeb (2006) \\
PhCN2 & $\mathrm{Cd}^{r}, \mathrm{Cu}^{r}$ a cured mutant of PhCN, pPhCN2 carrier & This study \\
PhCNM & $\mathrm{Ph}^{-}, \mathrm{Cd}^{-}, \mathrm{Cu}^{-}$a cured mutant of PhCN, Plasmidless & El-Deeb (2006) \\
Plasmids & & \\
pPhCN1 & $120 \mathrm{~Kb} \mathrm{Ph}^{+}$catabolic plasmid of $P$. putida PhCN & El-Deeb (2006) \\
pPhCN2 & $100 \mathrm{~Kb} \mathrm{Cd}^{r}, \mathrm{Cu}^{r}$, heavy metal resistant plasmid of $P$. putida PhCN & This study \\
\hline
\end{tabular}


nitrogen source and $0.5 \mathrm{mM}$ phenol as a carbon source. Cells were harvested by centrifugation at $10,000 \times g$ for $10 \mathrm{~min}$ at $4{ }^{\circ} \mathrm{C}$. The pellets were washed twice in $50 \mathrm{mM}$ phosphate buffer and were disrupted sonically at $4{ }^{\circ} \mathrm{C}$. Cellular debris was removed by centrifugation $\left(12,000 \times g\right.$ for $20 \mathrm{~min}$ at $\left.4{ }^{\circ} \mathrm{C}\right)$. The enzymes activity were measured by incubating the crude enzymes extract with $100 \mu \mathrm{M}$ catechol or phenol in $33 \mathrm{mM}$ Tris- $\mathrm{HCl}$ (pH 8.0), containing $1.3 \mathrm{mM}$ EDTA and $3.3 \mathrm{mM} 2$-mercaptoethanol, at $25^{\circ} \mathrm{C}$. The activity of catechol-2,3-dioxygenase was determined from the rate of $\alpha$-oxymuconic semialdehyde formation $(\alpha=375$ $\mathrm{nm}, \mathrm{E}=33.4 \mu \mathrm{M} / \mathrm{cm})$. The activity of catechol-1,2 dioxygenase was determined from the rate of cis-cis muconate formation $(\alpha=260, E=16.9 \mu \mathrm{M} / \mathrm{cm})$. The specific enzyme activity was expressed in nano moles of the cofactor consumed or the product formed in 1 min per $1 \mathrm{mg}$ of total bacterial protein. The protein concentration was determined spectrophotometrically according to Lowery et al. (1951).

\section{Plasmid analysis}

Plasmids were analyzed from cells grown in liquid media under selective conditions given by either metals or the carbon source. Plasmids of $P$. putida $\mathrm{PhCN}$ strains and its derivatives were analyzed according to the method of Kado and Liu (1981). Standard DNA techniques were used as described previously (Sambrook et al., 1989). For plasmids analysis, 0.7\% (wt/vol) agarose gels with Tris borate-EDTA buffer were employed. The size estimate of the isolated plasmid was obtained by comparing relative mobility on agarose gel with standard molecular markers.

\section{Stability, curing and conjugation}

The stability of degradation and heavy metal resistance properties were monitored by the growth of $\mathrm{PhCN}$ and its derivatives on glucose or LB broth. For chemical curing, culture was grown on LB broth containing various concentrations of mitomycin $C(5,10$, and 20 $\mu \mathrm{g} / \mathrm{mL}$ ), on a rotary shaker at $30{ }^{\circ} \mathrm{C}$ for $48 \mathrm{~h}$. Appropriate dilutions were spread on LB agar plates. Isolated colonies were replicated on LB plus metals and Tris-medium plus phenol and heavy metal plates. $\mathrm{Ph}^{-}$ and $\mathrm{Cd}^{-}, \mathrm{Cu}^{-}$were scored and reported as percent of curing. The conjugation between donor PhCN and recipient $\mathrm{PhCNM}$ was performed by liquid mating technique. Donor strains were grown overnight in LB broth in the presence of one selective metal. PhCNM recipients were usually cultivated until reach the latelogarithmic growth phase. Cells were harvested, washed gently and suspended in sterile LB broth (cell density $6.4 \times 10^{8} \mathrm{cell} / \mathrm{mL}$ ). Equal volume of cell suspensions were mixed together without shaking at 30 ${ }^{\circ} \mathrm{C}$ for $24 \mathrm{~h}$. Transconjugants were selected on heavy metal-Ph double selection plates and confirmed by growing them in MSM containing $\mathrm{Ph}$ in case of PhCN1 or heavy metals in case of PhCN2.

\section{RESULTS AND DISCUSSION}

\section{Native plasmids in P. putida PhCN}

Plasmid DNA analysis of $P$. putida strain PhCN cultures grown on phenol and cyanide indicated the presence of two large plasmid elements (El-Deeb, 2006). Plasmid curing experiments produced a plasmid-free strain named as PhCNM, a variant containing the $120 \mathrm{~kb}$ plasmid ( $\mathrm{pPhCN} 1$ ) named as $\mathrm{PhCN} 1$ and a strain harboring $100 \mathrm{~kb}$ plasmid (pPhCN2) named as PhCN2. Based on the fact that subsequent plasmid curing experiments demonstrated that the ability to utilize phenol was encoded by the $120 \mathrm{~kb}$ plasmid, whereas the ability to utilize cyanide appeared to be encoded by the chromosome (El-Deeb, 2006). However, the function of the second plasmid (pPhCN2) still unknown.

The present study showed that the pPhCN2 plasmid had no role in phenol degradation (Figures 1 to 4 , Table 2). To investigate the correlation between the resistance to $\mathrm{Zn}^{2+}, \mathrm{Cu}^{2+}, \mathrm{Ni}^{2+}$, and $\mathrm{Cd}^{2+}$ in relation to the presence of second large plasmid pPhCN2, mitomycin $\mathrm{C}$ was used to cure strain PhCN2 from its plasmid. Loss of the cadmium, copper, zinc, and nickel property was used for selection. Several hundreds clones were screened for heavy metals resistance deficient mutants. Most of the obtained mutants were sensitive to both cadmium and copper yet retained their resistance to other two metals of $\mathrm{Ni}^{2+}$ and $\mathrm{Zn}^{2+}$ (Table 2).

Conjugation studies also indicated that $\mathrm{pPhCN2}$ $(100 \mathrm{~kb})$ was expressed for $\mathrm{Cd}^{2+}$ and $\mathrm{Cu}^{2+}$ resistance. Transfer of $\mathrm{Cu}^{2+}$ and $\mathrm{Cd}^{2+}$ from strain $\mathrm{PhCN}$ or PhCN2 to strain PhCNM occurred at frequency of $10^{-7}$ to $10^{-8}$, which was comparable to the frequency reported previously when a plasmid-free derivative of strain $\mathrm{PhCN}$ was used as the recipient strain (Mergeay et al., 1985).

\section{Stability of plasmids}

The stability of phenol degradation and heavy metal resistance properties of PhCN strain and its variants was monitored as described in material and methods. Different variants, PhCN1 (contained pPhCN1) and PhCN2 (contained pPhCN2) were obtained. Each plasmid in these variants remained stable and retained the determined phenotype phenol degradation $\left(\mathrm{ph}^{+}\right)$ and/or heavy metal resistance $\left(\mathrm{Cd}^{r} / \mathrm{Cu}^{r}\right)$ after several passages in non selective medium. In the wild type strain $\mathrm{PhCN}$ (contained pPhCN1, pPhCN2), both plasmids were also maintained stably and retained the determined phenotype of $\mathrm{ph}^{+}$and $\mathrm{Cd}^{r} / \mathrm{Cu}^{r}$ after several passages in a non selective medium.

Minimal inhibitory concentration (MIC) of $\mathrm{Cd}^{2+}, \mathrm{Cu}^{2+}$, $\mathrm{Ni}^{2+}$, and $\mathrm{Zn}^{2+}$ against studied bacterial variants

In the preliminary screening, the ability of $P$. putida $\mathrm{PhCN}$ and its derivatives; PhCN1, PhCN2, and PhCNM, 
Mal. J. Microbiol. Vol 5(2) 2009, pp. 94-103

Table 2: MICs of heavy metals for $P$. putida $\mathrm{PhCN}$ and its derivatives in different cultural conditions

\begin{tabular}{|c|c|c|c|c|c|c|c|c|c|c|c|c|c|c|c|c|}
\hline \multirow{2}{*}{$\begin{array}{l}\text { Bacterial } \\
\text { strains }\end{array}$} & \multicolumn{4}{|c|}{ MIC of $\mathrm{Cd}^{2+}(\mathrm{mM})$} & \multicolumn{4}{|c|}{ MIC of $\mathrm{Cu}^{2+}(\mathrm{mM})$} & \multicolumn{4}{|c|}{ MIC of $\mathrm{Zn}^{2+}(\mathrm{mM})$} & \multicolumn{4}{|c|}{ MIC of $\mathrm{Ni}^{2+}(\mathrm{mM})$} \\
\hline & LB & $\begin{array}{l}\text { MS + } \\
\text { G }\end{array}$ & $\begin{array}{l}\text { MS + } \\
\text { Ph }\end{array}$ & $\begin{array}{l}\mathrm{MS}+\mathrm{CN} \\
+\mathrm{Ph}\end{array}$ & LB & $\begin{array}{l}\text { MS + } \\
\text { G }\end{array}$ & $\begin{array}{l}\text { MS + } \\
\text { Ph }\end{array}$ & $\begin{array}{l}\mathrm{MS}+ \\
\mathrm{CN}+\mathrm{Ph}\end{array}$ & LB & $\begin{array}{l}\text { MS + } \\
\text { G }\end{array}$ & $\begin{array}{l}\text { MS + } \\
\text { Ph }\end{array}$ & $\begin{array}{l}\mathrm{MS}+ \\
\mathrm{CN}+\mathrm{Ph}\end{array}$ & LB & $\begin{array}{l}\text { MS + } \\
\text { G }\end{array}$ & $\begin{array}{l}\text { MS + } \\
\text { Ph }\end{array}$ & $\begin{array}{l}\mathrm{MS}+ \\
\mathrm{CN}+\mathrm{Ph}\end{array}$ \\
\hline $\mathrm{PhCN}$ & 2.00 & 1.50 & 1.00 & 0.800 & 1.80 & 1.20 & 1.00 & 0.85 & 1 & 0.9 & 0.60 & 0.50 & 1.2 & 0.9 & 0.60 & 0.40 \\
\hline PhCN1 & 0.05 & 0.04 & 0.03 & 0.015 & 0.04 & 0.03 & 0.02 & 0.01 & 1 & 0.8 & 0.02 & 0.01 & 1.2 & 0.8 & 0.60 & 0.40 \\
\hline PhCN2 & 2.00 & 1.50 & 0.00 & 0.000 & 1.80 & 1.20 & 0.00 & 0.00 & 1 & 0.8 & 0.00 & 0.00 & 1.2 & 0.9 & 0.00 & 0.00 \\
\hline PhCNM & 0.04 & 0.04 & 0.00 & 0.000 & 0.04 & 0.04 & 0.00 & 0.00 & 1 & 0.7 & 0.00 & 0.00 & 1.2 & 0.8 & 0.00 & 0.00 \\
\hline
\end{tabular}
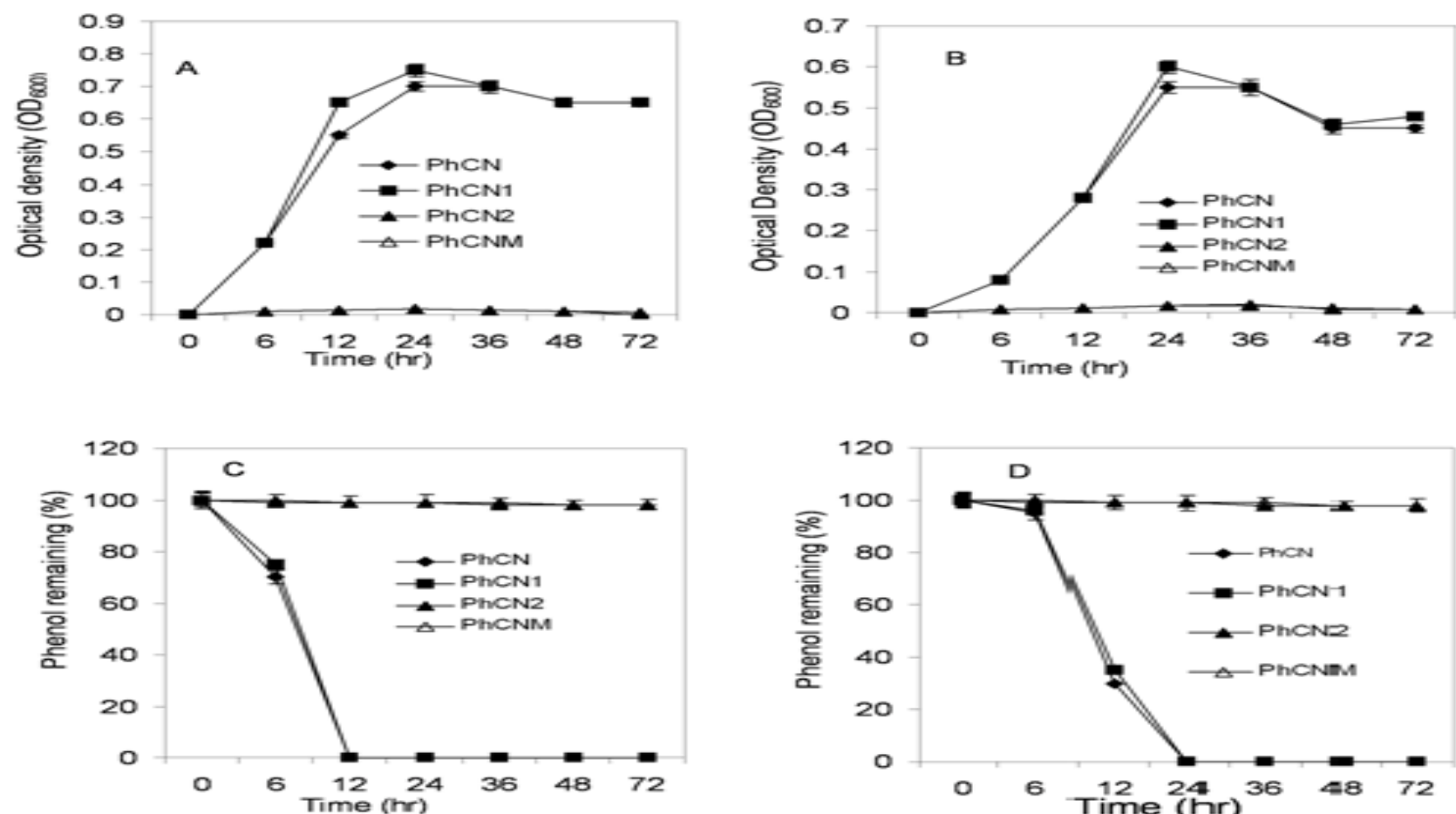

Figure 1: Bacterial growth and phenol utilization by $P$. putida PhCN and its derivatives PhCN1, PhCN2, PHCNM in minimal medium amended with ammonium ions (A, C) and/or cyanide (B, D) as a sole nitrogen source, in absence of metals ions 
to form confluent growth in the presence of incremental concentrations of studied metal salts was evaluated. On complete medium (LB), the wild type strain PhCN and its variant $\mathrm{PhCN} 2$ exhibited the highest resistance to $\mathrm{Cd}^{2+}$ and $\mathrm{Cu}^{2+}$ in comparison with the other strains, PhCN1and PhCNM (Table 2). However, the MICs of $\mathrm{Zn}^{2+}$, and $\mathrm{Ni}^{2+}$ for tested variants were very close.

It has been previously demonstrated that the interference of a high phosphate content in the usual minimal medium with a metal effect can lead to the over estimation of the MIC (Mergeay et al., 1985). Therefore, in the present work, levels of resistance in wild type strain PhCN and its cured derivatives to $\mathrm{Zn}^{2+}, \mathrm{Cu}^{2+}, \mathrm{Ni}^{2+}$, and $\mathrm{Cd}^{2+}$ were determined on Tris-medium supplemented with glucose as the sole carbon and energy source. As presented in Table 2, for the resistance variants $\mathrm{PhCN}$ and PhCN2, MIC of $\mathrm{Cd}^{2+}(1.5 \mathrm{mM})$ and $\mathrm{Cu}^{2+}(1.2 \mathrm{mM})$ were much higher than in sensitive strain PhCN1 $(0.03$ $\mathrm{mM}$ and $0.02 \mathrm{mM}$ for $\mathrm{Cd}^{2+}$ and $\mathrm{Cu}^{2+}$, respectively). No significant difference in the MICs of $\mathrm{Zn}^{2+}$ and $\mathrm{Ni}^{2+}$ among the four strains was observed. Furthermore, the MICs of $\mathrm{Cd}^{2+}, \mathrm{Zn}^{2+}, \mathrm{Cu}^{2+}$ and $\mathrm{Ni}^{2+}$ for tested strains in the Trismedium were lower than those observed in the LB medium (Table 2). This result was in harmony with those mentioned by Mergeay et al. (1985). They stated that MICs of heavy metals in Tris-medium were lower than those observed in a rich medium. On the other hand, the MICs of $\mathrm{Cd}^{2+}, \mathrm{Zn}^{2+}, \mathrm{Cu}^{2+}$ and $\mathrm{Ni}^{2+}$ in the presence of phenol and cyanide as sole carbon and nitrogen sources, respectively, for tested strains were lower than those observed in the Tris-medium supplemented with ammonium as a nitrogen source (Table 2). These results are consistent with findings of Barbieri et al. (1996) that the MICs of metals for catabolic strains in the presence of aromatic compounds as the only source of carbon are only slightly lower than those evaluated in the presence of glucose or malate.

\section{Growth kinetics}

\section{Growth on phenol in the absence of heavy metals}

Preliminary assays were performed to evaluate the growth rate of wild type strain PhCN and its derivatives; PhCN1, PhCN2, and PhCNM (plasmidless) on MSM medium free from heavy metals and supplied with phenol and ammonium or cyanide as a sole source of carbon and nitrogen, respectively. The results presented in Figure 1 (A-D) indicated that both strains which harboured a catabolic plasmid pPhCN1 were able to degrade the compound at similar rate. However, strains grown on MSM medium free from heavy metals and supplied with phenol and cyanide revealed a decrease in the growth rate as well as the rate of phenol consumption comparing to the strains supplied with ammonium salt as a nitrogen source. Similar findings were reported by Arutchelvan et al. (2005) for Pseudomonas sp. grown on phenol and cyanide.
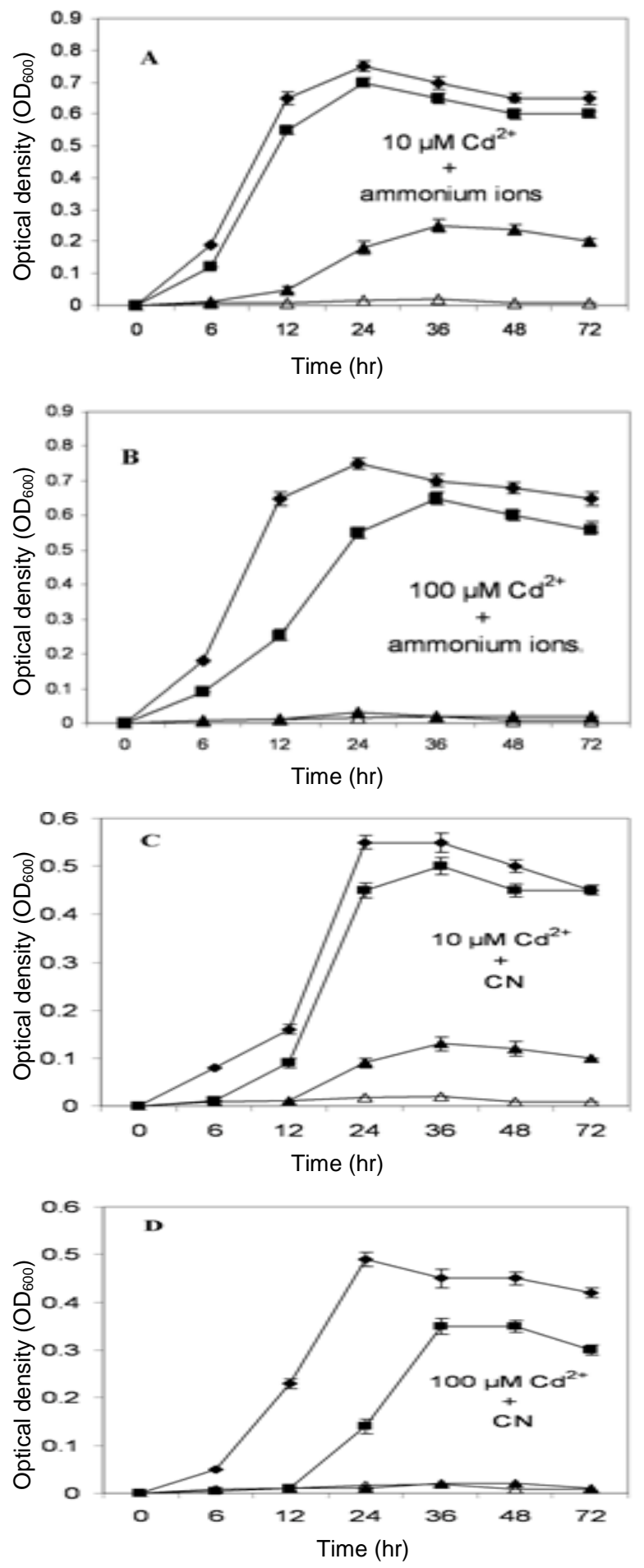

Figure 2: Effect of cadmium concentrations on the growth of $P$. putida $\mathrm{PhCN}$ and its derivatives on phenol and ammonium ions/or cyanide as a sole carbon and nitrogen source respectively. Strains symbols: $(\bullet) \mathrm{PhCN}$ without $\mathrm{Cd}^{2+}$ (control); (๘), $\mathrm{PhCN} ;(\boldsymbol{\Delta})$ PhCN1 and $(\Delta)$, PhCN2 

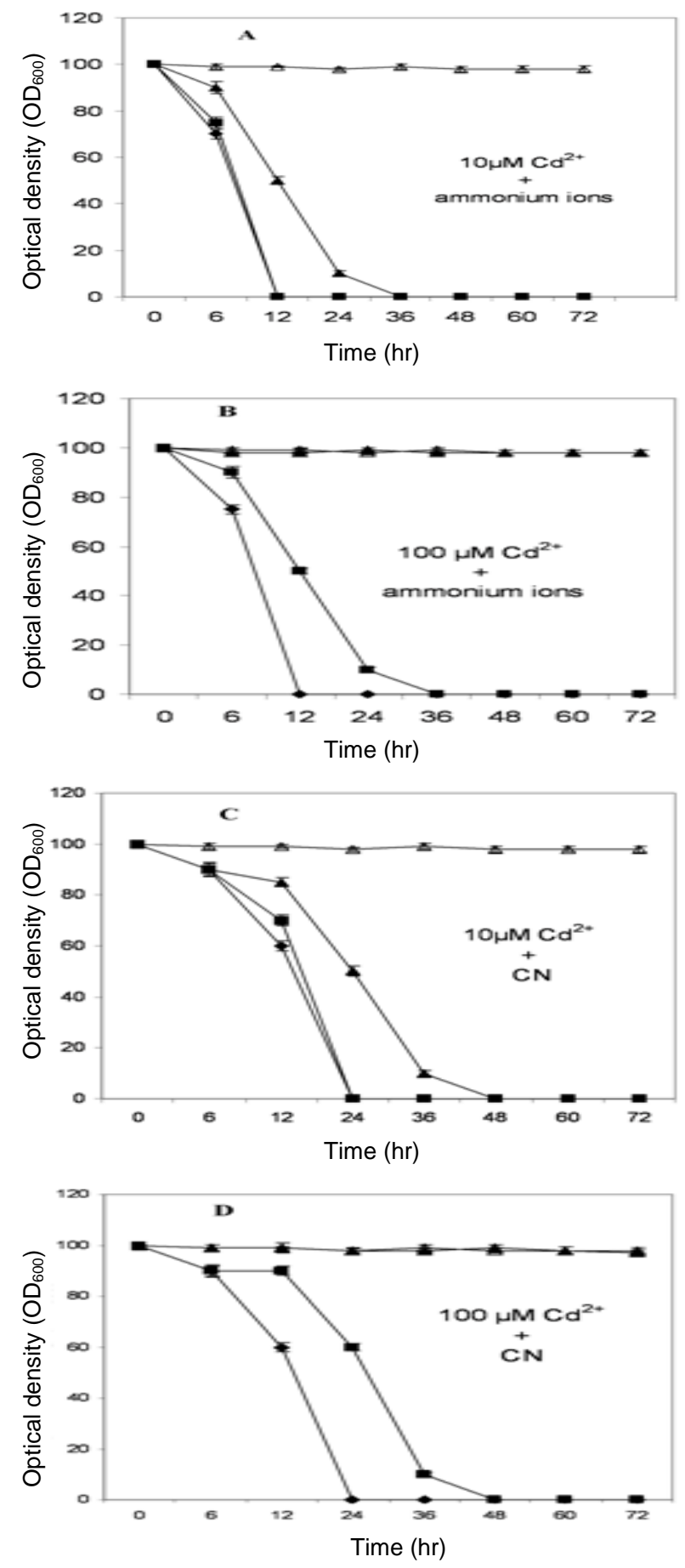

Figure 3: Effect of cadmium concentrations on the phenolutilization by $P$. putida $\mathrm{PhCN}$ and its derivatives in minimal medium amended with ammonium ions/or cyanide as a nitrogen source respectively. Strains symbols: $(\bullet) \mathrm{PhCN}$ without $\mathrm{Cd}^{2+}$ (control); $(\mathbf{a}), \mathrm{PhCN} ;(\boldsymbol{\Delta}) \mathrm{PhCN} 1$ and $(\Delta), \mathrm{PhCN} 2$

\section{Growth on phenol in the presence of the cadmium}

The effect of cadmium on growth parameters and phenol consumption by resistant strain PhCN (pPhCN1, pPhCN2) and sensitive strain PhCN1 ( $\mathrm{pPhCN} 1$ ) was investigated. Cadmium at concentration of $10 \mu \mathrm{M}$ in MSM medium with phenol and ammonium as a sole source of carbon and nitrogen, respectively, did not affect the growth rate of $\mathrm{PhCN}$, whereas, the growth of sensitive strains was significantly reduced comparing with that of the cadmium free medium (Figure 2A). Phenol consumption by sensitive strain $\mathrm{PhCN1}$, was significantly reduced compared to that of the free-cadmium MSM (Figure 3A) (Amor et al., 2001; Siunova et al., 2007). However, the addition of cadmium at a concentration of $10 \mu \mathrm{M}$ did not change the rate of phenol consumption by resistant strain $\mathrm{PhCN}$ as compared to that of the free-cadmium MSM (Figure 3A) (Siunova et al., 2007).

Increasing concentration of cadmium by ten-fold (100 $\mu \mathrm{M})$ caused a complete inhibition of growth in sensitive strain PhCN1 (Figure 2B), whereas, the growth and phenol consumption by resistance strain $\mathrm{PhCN}$ was slightly reduced as compared to that of the free-cadmium MSM (Figure 2B and 3B). Previously a similar finding has been reported for the multifunctional strains of Alcaligenes eutrophus that bear plasmids of resistance to bivalent cations, pMOL28 (cnr-Cor $\left.\mathrm{N}^{r}\right)$ and pMOL30 (czc-Cor $\mathrm{Zn}^{r}$ $\mathrm{Cd}^{r}$ ), and catabolic plasmids of biodegradation of polychlorinated biphenyls, pSS50 $\left(\mathrm{BpH}^{+} / \mathrm{Cbp}^{+}\right)$, and 2,4dichlorophenoxyacetic acid, pJP4 $\left(\mathrm{Tfd}^{+}\right)$are effectively degraded the above pollutants in the presence of metals (Collard et al., 1994; Mergeay, 1995).

The combination effects of heavy metals and cyanide on bacterial growth and phenol degradation were investigated. As presented in Figure $2 \mathrm{C}$, addition of cadmium $(10 \mu \mathrm{M})$ to MSM containing phenol and cyanide as the sole source of carbon and nitrogen, respectively, showed a slightly decrease in the growth rate and phenol consumption by resistant strain PhCN (Figure $3 \mathrm{~A}$ and $3 \mathrm{C}$ ), whereas, induced a significant decrease in bacterial growth and retarded phenol consumption by sensitive strain PhCN1 (Figure 2C and 3C).

A ten-fold increase of cadmium $(100 \mu \mathrm{M})$ combined with cyanide as a nitrogen source caused a $12 \mathrm{~h}$ lagphase (Figure 2D) and phenol consumption was less active by resistant strain $\mathrm{PhCN}$ as compared to that of the MSM free cadmium. Under the same conditions, the growth of sensitive strain PhCN2 was completely inhibited (Figure 2B and 2D). This may be due to the fact that when various toxicants were added together, the growth of almost all bacterial isolates was very poor or absent, suggesting that the tolerance level of heavy metal resistance strains is affected by many xenobiotics (De et al., 2003).

\section{Growth on phenol in the presence of the copper}

Growth response of the PhCN and its variants in the presence of cupric chloride was presented in Figure 4. At low concentration $(10 \mu \mathrm{M})$ in MSM supplemented with 
phenol and ammonium as a sole source of carbon and nitrogen, respectively, the growth rate of resistant strain PhCN was not affected, however the growth rate of the sensitive strain PhCN1 was significantly reduced (Figure 4A). Phenol consumption by resistance strain $\mathrm{PhCN}$ was less active as compared to the MSM free from copper (Figure 5A), whereas, phenol consumption by sensitive strain was significantly reduced (Figure $5 A$ ). This result was in agreement with previous results of Lin et al. (2006) which showed that copper exhibited high toxicity at relatively low concentrations of $10 \mathrm{mg} / \mathrm{L}$.

The addition of copper at a concentration $10 \mu \mathrm{M}$ to the MSM containing phenol and cyanide as a sole source of carbon and nitrogen respectively, produced no appreciable affect on the growth and phenol consumption by resistance variant, while the growth of sensitive strain was significantly reduced (Figure $4 \mathrm{C}$ and $5 \mathrm{C}$ ).

A ten-fold increase of copper $(100 \mu \mathrm{M})$ in MSM supplemented with phenol and cyanide as a sole source of carbon and nitrogen source respectively, caused a long lag-phase $(12 \mathrm{~h})$ and required long time $(60 \mathrm{~h})$ for complete phenol consumption by resistance strain $\mathrm{PhCN}$ (Figure 4D and 5D). However, the addition of copper at a concentration of $100 \mu \mathrm{M}$ to MSM was completely inhibited the growth of sensitive strain (Figure 3D and 4D) (Sokhn et al., 2001).

By comparing the obtained results in Figure 1 to 4 , it can be concluded that, low concentration of both $\mathrm{Cu}^{2+}$ and $\mathrm{Cd}^{2+}(10 \mu \mathrm{M})$ did not exhibit any significant inhibitory effect on microbial growth of resistant variants in presence of ammonium or cyanide as a nitrogen source. However, both metals at low concentration significantly reduced the growth of sensitive strain (Siunova et al., 2007). Ten-fold increase of both metals concentration caused slightly increased a lag phase in the case of resistant variant PhCN whereas completely inhibited the growth of the sensitive strain PhCN1. However, in the presence of $\mathrm{KCN}$ as a nitrogen source, the overall bacterial growth and phenol consumption was less than that observed when the bacteria were grown in the presence of ammonium as a nitrogen source. Medium composition affects the degree and pattern of metals inhibition of organic pollutants biodegradation (Hoffman et al., 2005).

\section{Effect of metal ions on the phenol degradation enzyme activity}

The C230 pathway for catechol degradation during phenol metabolism in Pseudomonas sp. PhCN was previously demonstrated (El-Deeb, 2006). In order to study whether phenol degradation by the strain PhCN and its variants affected by different nitrogen source in presence and absence of metal ions, the variants were grown in LB medium and phenol - MSM media amended with different nitrogen sources in presence of metal ions. When the activity of C230 enzyme was measured (Table 3 ), no C23O activity was detected in LB medium in the absence of phenol. In the presence of phenol, the activity of $\mathrm{C} 23 \mathrm{O}$ was negligible.
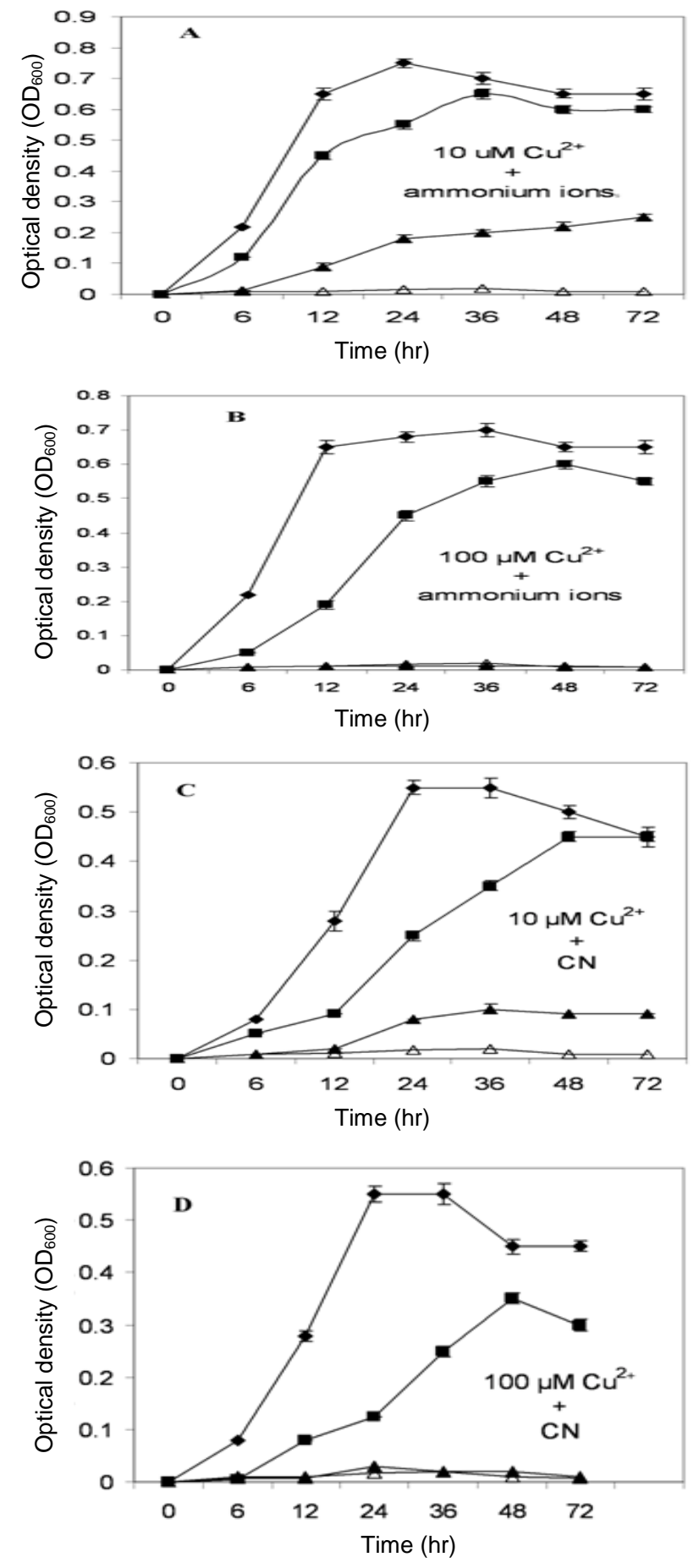

Figure 4: Effect of copper concentrations on the growth of $P$. putida $\mathrm{PhCN}$ and its derivatives on phenol and ammonium ions/or cyanide as a sole carbon and nitrogen source respectively. Strains symbols: $(\bullet) \mathrm{PhCN}$ without $\mathrm{Cu}^{2+}$

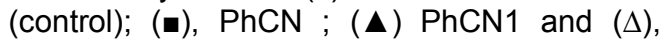
PhCN2 

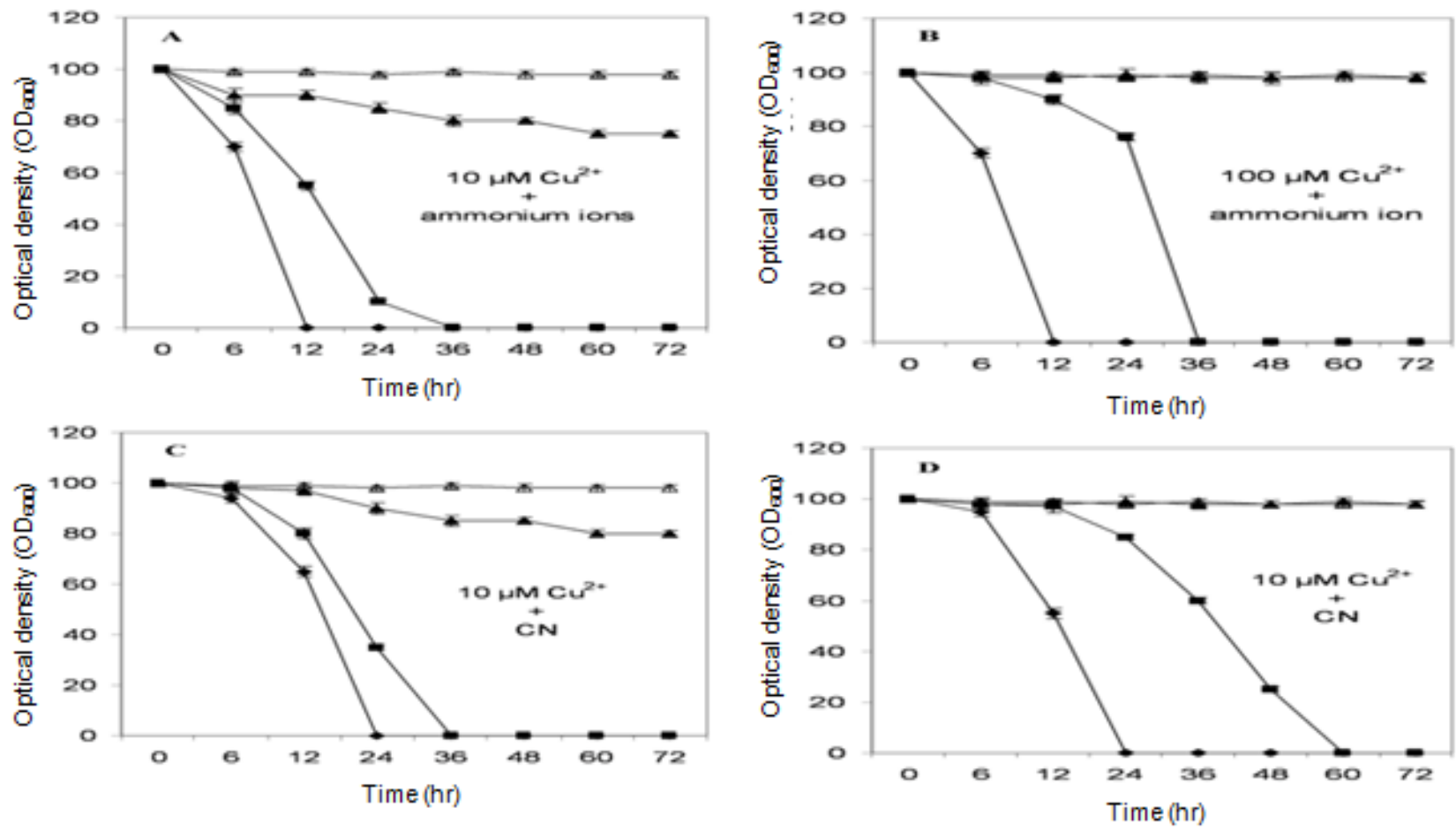

Figure 5: Effect of copper concentrations on the phenol utilization by $P$. putida $\mathrm{PhCN}$ and its derivatives in minimal medium amended with ammonium ions/or cyanide as a nitrogen source respectively. Strains symbols: $(\diamond) \mathrm{PhCN}$ without $\mathrm{Cu}^{2+}$ (control); (๘), PhCN ; $(\boldsymbol{\Delta}) \mathrm{PhCN} 1$ and $(\Delta), \mathrm{PhCN} 2$

In the absence of heavy metals, the $\mathrm{C} 23 \mathrm{O}$ activity was high when the cells were grown in the presence of phenol and ammonium salt as a sole source of carbon and nitrogen respectively (Table 3 ). In the presence of $\mathrm{KCN}$ as a nitrogen source, the overall enzyme activity was less than that observed in the presence of ammonium as a nitrogen source (Table 3 ).

The effect of $\mathrm{Cd}^{2+}$ or $\mathrm{Cu}^{2+}$ on the 2,3-dioxygenase enzyme activity in the MSM containing phenol and ammonium as a sole source of carbon and nitrogen respectively, was investigated. The results in Table 3 showed that both the metals had a severe inhibitory effect on the 2,3-dioxygenase activity in the sensitive strain while they had slight effect on the enzyme activity in resistant strain PhCN. (Nakazawa and Nakazawa,
1970; Yeom and Yoo, 1997 ). The effect of $\mathrm{Cd}^{2+}$ or $\mathrm{Cu}^{2+}$ was also found to exert a strong inhibitory effect on the enzyme activity in the presence of cyanide as a nitrogen source (Table 3 ). This could be attributed to enzymes produced into the extracellular environment often face higher concentration of metals, since they are not protected by cell-associated metal-detoxification mechanisms (Yeom and Yoo, 1997)

\section{CONCLUSIONS}

Multifunctional strain of $P$. putida strain $\mathrm{PhCN}$ that bear plasmids of resistance to bivalent cations, pPhCN2 $\left(\mathrm{Cd}^{r}\right.$, $\mathrm{Cu}^{r}$ ) and catabolic plasmids of biodegradation of phenol pPhCN1 $\left(\mathrm{Ph}^{+}\right)$are effectively degraded the above

Table 3: Specific activities of meta-cleaving enzyme C230 dioxygenase in a crude extract of parent strain $\mathrm{PhCN}$ and its derivatives grown on different substrate, enzyme was assayed as described in Materials and Methods

\begin{tabular}{|c|c|c|c|c|c|c|c|c|c|c|c|}
\hline \multirow{3}{*}{$\begin{array}{l}\text { Nitrogen source } \\
\text { Strains }\end{array}$} & \multicolumn{11}{|c|}{ Substrate } \\
\hline & \multicolumn{5}{|c|}{ In presence of ammonium ions } & \multicolumn{6}{|c|}{ In presence of cyanide } \\
\hline & TSM +G & $\begin{array}{l}\text { TSM } \\
\text { Ph }\end{array}$ & + & $\begin{array}{l}\text { TSM + } \\
\mathrm{Ph}+\mathrm{Cd}\end{array}$ & $\begin{array}{l}\mathrm{TSM}+ \\
\mathrm{Ph}+\mathrm{Cu}\end{array}$ & $\begin{array}{l}\text { TSM } \\
\text { G }\end{array}$ & + & $\begin{array}{l}\text { TSM } \\
\text { Ph }\end{array}$ & + & $\begin{array}{l}\text { TSM + } \\
\mathrm{Ph}+\mathrm{Cd}^{-}\end{array}$ & $\begin{array}{l}\text { TSM + } \\
\mathrm{Ph}+\mathrm{Cu}\end{array}$ \\
\hline PhCN (pPhCN1,pPhCN2) & 0.01 & 14.2 & & 12.2 & 11.4 & 0.01 & & 12.8 & & 11.6 & 10.8 \\
\hline PhCN1(pPhCN1) & 0.01 & 14.6 & & 0.4 & 0.2 & 0.01 & & 10.8 & & 0.09 & 0.02 \\
\hline PhCN2 (pPhCN2) & ND & ND & & ND & ND & ND & & ND & & ND & ND \\
\hline PhCNM(Plasmidless) & ND & ND & & ND & ND & ND & & ND & & ND & ND \\
\hline
\end{tabular}

Enzyme activity is given in $\mathrm{U} / \mathrm{mg}$ of protein.

ND, not detected; G, glucose; Ph, phenol; Cd, cadmium; Cu, copper 
pollutants in the presence of metals as compared with sensitive strain. The effect of $\mathrm{Cd}^{2+}$ or $\mathrm{Cu}^{2+}$ was also found to exert a strong inhibitory effect on the C23O dioxygenase enzyme activity in the presence of cyanide as a nitrogen source. However, the presence of heavy metal resistance plasmid alleviated the inhibitory effect of metals on the enzyme activity in resistant strain. These findings demonstrate the possibility of combining the plasmids of phenol catabolism, plasmids of resistance to heavy metals, and systems of chromosomal gene encoded for cyanide assimilation. This approach can be used for the creation of polyfunctional bacterial strains effective for bioremediation of soil polluted by phenol in combination with cyanide and heavy metals.

\section{REFERENCES}

Al-Saleh, E. and Obuekwe, C. (2005). Inhibition of hydrocarbon bioremediation by lead in a crude oil-contaminated soil. International Biodeterioration and Biodegradation 56, 1-7.

Amor, I., Kennes, C., and Veiga, M. C. (2001). Kinetics of inhibition in the biodegradation of monoaromatic hydrocarbons in the presence of heavy metals. Bioresource Technology 78, 181-185.

Arutchelvan, A., Kanakasabai, V., Nagarajan, S. and Muralikrishnan, V. (2005). Isolation and identification of novel high strength phenol degrading bacterial strains from phenol formaldehyde resin manufacturing industrial wastewater. Journal Hazardous Materials 27, 238-243.

Barbieri, P., Bestetti, G., Reniero, D., and Galli, E. (1996). Mercury resistance in aromatic compounds degrading Pseudomonas strains. FEMS Microbiology Ecology 20, 185-194.

Benka-Coker, M. O. and Ekundayo, J. A. (1998). Effects of heavy metals on growth of species of Micrococus and Pseudomonas in a crude oil/mineral salts medium. Bioresource Technology 66, 241-245.

Collard, J. M., Corbisier, P., Diels, L., Dong, Q., Jeanthon, C., Mergeay, M., Taghavi, S., van der Lelie, D., Wilmotte, A., and Wuertz, S. (1994). Plasmids for heavy metal resistance in Alcaligenes eutrophus $\mathrm{CH} 34$ : Mechanisms and Application. FEMS Microbiological Reviews 14, 405-414.

Chen, X., Shi, J., Chen, Y., Xu, X., Xu, S. and Wang, Y. (2005). Tolerance and absorption of copper and zinc by Pseudomonas putida CZ1 isolated from metal polluted soil. Candian Journal of Microbiology 52, 308-316.

De, J., Ramaiah, N., Mesquita, A., and Verleker, X.N. (2003). Tolerance to various toxicants by marine bacteria highly resistant to mercury. Marine Biotechnology 5, 185-193.
El-Deeb, A. B. (2006) Plasmid and chromosomemediated assimilation of phenol and cyanide in Pseudomonas sp. strain PhCN. Journal of Microbiology and Biotechnology 16, 10681077.

Folsom, B. R., Chapman, P. J. and Pritchard, R. (1990). Phenol and trichloroethylene degradation by Pseudomonas cepacia 4: Kinetics and interaction between substrates. Applied and Environmental Microbiology 56, 1279-1285.

Hoffman, R. D., Okon, J. L., and Sandrin, T. R. (2005). Medium composition affects the degree and pattern of cadmium inhibition of naphthalene biodegradation. Chemosphere 59, 919-927.

Hong, B. H., Chang, Y. S., Nam, I. H., Fortnagel, P., and Schmit, S. (2002). Biotransformation of 2,7-dichloro-and 1, 2, 3, 4-tetrachlorodibenzop-dioxin by Sphingomonas wittichii RW1. Applied and Environmental Microbiology 68, 2584-2588.

Jain, R. K. and Sayler, G. S. (1987). Problems and potential for in situ treatment of environmental pollutants by engineered microorganisms. Microbiological Science. 4, 59-63.

Kado, C. I., and Liu, S. T. (1981). Rapid procedure for detection and isolation of large and small plasmids. Journal of Bacteriology 145, 13651373.

Kuo, C-W., and Sharak Genthner, B. R. (1996). Effect of added heavy metals ions on biotransformation and biodegradation of 2chlorophenol and 3-chlorobenzoate in anaerobic bacterial consortia. Applied and Environmental Microbiology 62, 2317-2323.

Lin W. C., Chen, Y. S., Cheng, W. Y. ( 2006). Effect of metals on biodegradation kinetics for methyl tert-butyl ether. Biochemical Engineering Journal 32: 25-32.

Lowery, O. H., Rosenbrough, N. J., Farr, R. L., and Randall, R. J. (1951). Protein measurement with the folin phenolreagent. Journal of Biological Chemistry. 193, 265-275.

Malakul, P., Srinivasan, K. R., Wang, H. Y. (1998). Metal toxicity reduction in naphthalene biodegradation by use of metal-chelation adsorbents. Applied and Environmental Microbiology 64, 4610-4613.

Mergeay, M. (1995). Heavy metal resistances in microbial ecosystems. In: Molecular Microbiol Ecology Manual. Akkermans. A. D. L., de Bruijn, F. J., van Elsas, J. D., Trevors, J. T. (eds.). Kluwer Academic Publishers, Dordrecht. 6.1.7, 1-7.

Mergeay, M., Nies, D., Schiegel, H. G., Gerits, J., Charles, P., and Van Gijsegem, F. (1985). Alcaligenes eutrophus $\mathrm{CH} 34$ is a facultative chemolithotroph with plasmid-bound resistance 
to heavy metals. Journal of Bacteriology 162, 38-334.

Nakazawa, T. and Nakazawa, A. (1970). "pyrocatechase (Pseudomonas)", Method in Enzyme. 17A, 518.

Norena-Barroso, E., Sima- Lvarez, R., GoldBouchot, G., Zapata-Perez, O., (2004) Persistent organic pollutants and histological lesions in Mayan catfish Ariopsis assimilis from the Bay of Chetumal. Mexico. Marine Pollution Bulletin 48, 263-269.

Riis, V., Babel, W., Pucci, H.O. (2002). Influence of heavy metals on the microbial degradation of diesel fuel. Chemosphere 49, 559-568.

Roane, T. M., Josephson, J. L. and Pepper, I. L. (2001). Dual-bioaugmentation strategy to enhance remediation of co-contaminated soil. Applied and Environmental Microbiology 67, 3208-3215.

Roane, T. M. and Pepper, I. L. (1997). Microbial remediation of soils co-contaminated with 2,4dichlorophenoxy acetic acid and cadmium, In: proceedings of the $12^{\text {th }}$ Annual Conference on Hazardous Waste Research: Building Partnership for Innovative Technologies, Kansas City, Mo. 343-356.

Said, W. A. and Lewis, D. L. (1991). Quantitative assessment of the effects of metals on microbial degradation of organic chemicals. Applied and Environmental Microbiology 57, 1498-1503.

Sambrook, J., Fritsch, E. F., Maniatis, T. (1989). Molecular cloning: a Laboratory manual, $2^{\text {nd }}$ ed. Cold Spring Harbor Laboratory Press Cold Spring Harbor, New York.

Silva, A. D. A., Pereira, P. M., Filho, S. G. and Hofer, E. (2007). Utilization of phenol in the presence of heavy metals by metal-tolerant non-fermentative Gram-negative bacteria isolated from wastewater. Microbiology 49, 6873.

Siunova, V. T., O.Anokhina, T., Mashukova, A. V., Kochetkov, V. V. and Boronin, A. M. (2007). Rhizosphere strain Pseudomonas chlororaphis capable of degrading naphthalene in the presence of cobalt/nickel. Microbiology 76, 182-188.

Sokhn, J., De Leij, F. A. A. M., Hart, T. D., and Lynch, T. ( 2001). Effect of copper on the degradation of phenanthrene by soil microorganism. Letter in Applied Microbiology 33, 164-168.

Springael, D., Diels, I., Hooyberghs, H., Krepsk, S., and Mergeay, M. (1993). Construction and characterization of heavy metal resistant haloaromatic-degrading Alcaligenes eutrophus strains. Applied and Environmental. Microbiology 59, 334-339.

Wasi, S., Jeelani, G., and Ahmad, M. (2008). Biochemical characterization of a multiple heavy metal, pesticides and phenol resistant Pseudomonas fluorescens strain. Chemosphere 71, 1348-1355.

White, V. E., and Knowles, C. J. (2003). Degradation of cooper-NTA by Mesorhizobium sp. NCIMB 13524. International Biodeterioration and Biodegradation. 52, 143150.

Yeom, H. S., and Yoo, J. Y. (1997). Overcoming the inhibition effects of metal ions in the degradation of benzene and toluene by Alcaligenes xylosoxidans Y234. Korean Journal of Chemical. Engineering 14, 204-208. 